EXTENDED REPORT

\title{
The HELLP syndrome in the antiphospholipid syndrome: retrospective study of 16 cases in 15 women
}

\author{
D Le Thi Thuong, N Tieulié, N Costedoat, M-R Andreu, B Wechsler, D Vauthier-Brouzes, \\ O Aumaître, J-C Piette
}

Ann Rheum Dis 2005;64:273-278. doi: 10.1136/ard.2003.019000

\begin{abstract}
See end of article for authors' affiliations

Correspondence to: Dr D Le Thi Thuong, Departments of Internal Medicine, Groupe Hospitalier PitiéSalpêtrière, 47-83 Boulevard de l'Hôpital, 75651 Paris cedex 13, France; du.boutin@ psl.ap-hop-paris.fr
\end{abstract}

Accepted 6 July 2004

\begin{abstract}
Objective: To study the characteristics of the haemolysis, elevated liver enzymes, low platelets (HELLP) syndrome in the antiphospholipid syndrome (APS) and its influence on the subsequent pregnancies. Methods: This was a retrospective analysis of 16 episodes of HELLP complicating APS in 15 women. Results: HELLP was complete in 10 cases and partial in six. It occurred during the second trimester in seven cases (the earliest at 18 weeks' gestation), the third trimester in seven cases, and the day following delivery in two cases. Pre-eclampsia was present in six cases and eclampsia in five. Outcome of pregnancies was: live birth $(n=8)$, stillbirth $(n=2)$ and fetal death $(n=6)$. APS was primary in nine women and secondary to systemic lupus erythematosus (SLE) in six. HELLP revealed primary APS in six cases. Seven women were not treated. Low dose aspirin was empirically prescribed in one woman whose APS had been undiagnosed despite a history of two fetal deaths. In the other women, therapy consisted of aspirin $(n=8)$, low molecular weight heparin with a dose varying between 3000 and $12000 \mathrm{U}$ daily $(n=5)$, and high dose immunoglobulin every 4 weeks $(n=2)$, hydroxychloroquine $(n=4)$, and prednisone $(n=6)$. Six women had seven subsequent pregnancies, 3-6 years after the complicated pregnancy. HELLP recurred at 33 weeks' gestation in one woman with SLE treated with prednisone, hydroxychloroquine, aspirin, and enoxaparin, and pregnancy ended in live birth. One woman became pregnant after in vitro fertilisation and embryo transfer, but pregnancy ended in fetal death despite prednisone, hydroxychloroquine, and enoxaparin. Four women had five uneventful pregnancies with $100 \mathrm{mg}$ daily aspirin and heparin.

Conclusions: APS may be revealed by HELLP. In APS, HELLP is associated with pre-eclampsia/eclampsia in most cases and seems to occur earlier than in the general population. Heparin plus aspirin may prevent obstetric complications in the subsequent pregnancies.
\end{abstract}

ncidence of haemolysis, elevated liver enzymes, low platelets (HELLP) syndrome in pregnancy has been estimated at $0.01-0.2 \%$ in the general population, and at $10-12 \%$ in pregnancies complicated with pre-eclampsia/ eclampsia. During a 15 year period in a tertiary care centre serving a population area with 40000 deliveries per year, 442 HELLP syndromes were observed. ${ }^{1}$ During the same period, 2331 pregnancies were complicated by pre-eclampsia or eclampsia. Reports of HELLP syndrome complicating APS are scarce. We report a series of 16 episodes of HELLP syndrome complicating primary or secondary APS in 15 women, and describe its characteristics and its influence on the subsequent pregnancies.

\section{PATIENTS AND DEFINITIONS}

We retrospectively reviewed the data of 16 pregnancies in 15 women with APS complicated with HELLP syndrome. Diagnosis of APS was based on the international criteria. ${ }^{2}$ Lupus anticoagulant (LA) was usually detected by activated partial thromboplastin time (PTT), diluted thromboplastin time, or kaolin clotting time. Abnormal coagulation times were confirmed by mixing patient and control plasma on a $1: 1$ ratio in order to exclude clotting factor deficiencies. IgG and IgM anticardiolipin (aCL) antibodies were measured by ELISA. IgG and IgM rates were reported as negative if $<15 \mathrm{U} /$ $\mathrm{ml}$, as low positive at $16-25 \mathrm{U} / \mathrm{ml}$, as medium positive at 26$80 \mathrm{U} / \mathrm{ml}$ and as high positive if $>80 \mathrm{U} / \mathrm{ml}$.

Diagnosis of HELLP was based on the presence of haemolysis (anaemia with characteristic peripheral blood smear), lactate dehydrogenase (LDH) over the upper normal value or total bilirubin $>12 \mathrm{mg} / \mathrm{l}$, elevated alanine aminotransferase (AAT) >twofold the upper normal value, and nadir platelet count below $125000 / \mathrm{mm}^{3}$. Complete HELLP was defined by presence of all criteria, and partial HELLP by the presence of two criteria. ${ }^{3}$ Diagnosis of systemic lupus erythematosus (SLE) was based on the revised ACR criteria. ${ }^{4}$ The other definitions were: (a) embryonic loss (spontaneous termination of pregnancy prior to 10 weeks' gestation)); (b) fetal death (according to Branch's definition, ${ }^{5}$ death of a fetus demonstrated to be alive at or beyond 10 weeks' gestation); (c) premature birth (termination of pregnancy with a live birth below 37 weeks' gestation); (d) full term birth (termination of pregnancy with a live birth between 38 and 40 weeks); (e) intrauterine growth retardation (IUGR) (birth weight below the 10th centile for the stated gestation); $(f)$ hypertension (diastolic pressure $>90$ $\mathrm{mm} \mathrm{Hg}$ ); $(\mathrm{g})$ pre-eclampsia (hypertension complicated with proteinuria $\geqslant 0.5 \mathrm{~g} / 24$ hours or oedema or both); and $(h)$ eclampsia (pre-eclampsia complicated with seizures or fitting.

\section{RESULTS}

At the first episode of HELLP, the mean age was 30 years (range 22-37). Seven women were nulliparous. Pregnancy was the second in four women, the third in two women, the fourth for one woman, and the tenth for one other woman.

Abbreviations: AAT, alanine aminotransferase; $\mathrm{aCL}$, anticardiolipin; APS, antiphospholipid syndrome, APTT, activated partial thromboplastin time; HELLP, haemolysis, elevated liver enzymes, low platelets; IUGR, intrauterine growth retardation; LA, lupus anticoagulant; LDH, lactate dehydrogenase; LMWH, low molecular weight heparin; SLE, systemic lupus erythematosus 
Eight women had been previously pregnant with a total of 15 pregnancies. Two women had had a total of four normal pregnancies before SLE/APS onset. Hence, 11 pregnancies were complicated with fetal death $(n=9)$, embryonic loss $(\mathrm{n}=1)$, and live birth at full term of a growth retarded baby $(\mathrm{n}=1)$.

APS was primary in nine women and secondary to SLE in six. Primary APS was known in only one of the women, who had a history of repeated fetal loss and stroke; 2/8 women with unknown primary APS had been undiagnosed, although there was a suggestive history. One woman had a history of two successive fetal deaths, and another woman had a false positive syphilis test. Hence, HELLP revealed primary APS in six cases.

Of the six women with SLE, APS was known in four, who had a history of thrombophlebitis with fetal death $(n=2)$, repeated fetal deaths $(\mathrm{n}=1)$, and ischaemic cerebral stroke with embryonic loss $(n=1)$. Two women with SLE had prior asymptomatic aCL until onset of HELLP complicated with fetal death $(\mathrm{n}=2)$.

Seven women whose pregnancy was complicated by HELLP had not been previously treated. Low dose aspirin was empirically prescribed in one woman whose APS had been undiagnosed despite a history of two fetal deaths. Three women were treated with aspirin plus low molecular weight heparin (LMWH) with a dose varying between 3000 and $8000 \mathrm{U}$ daily. Two women with prior complicated pregnancy under aspirin and LMWH were treated with LMWH $12000 \mathrm{U}$ daily, aspirin $100 \mathrm{mg} /$ day, and high dose immunoglobulin $80 \mathrm{~g}$ twice daily every 4 weeks. One woman with primary ASP complicated with autoimmune thrombocytopenia was treated with hydroxychloroquine and $5 \mathrm{mg}$ daily prednisone. All women with SLE, except one woman who was not treated, received prednisone with a dose ranging between 5 and $30 \mathrm{mg} /$ day and aspirin $100 \mathrm{mg} /$ day. Hydroxychloroquine was maintained in three women and withdrawn in two others.

HELLP was complete in 10 cases and partial in six. It occurred during the second trimester in seven cases (the earliest at 18 weeks' gestation), the third trimester in seven, and in two cases, it appeared the day following delivery (fig l). The main characteristics of HELLP are summarised in table 1.

Outcome of pregnancy was: live birth of a eutrophic $(n=3)$ or a hypotrophic baby $(n=5)$, at full $(n=2)$ or premature term $(n=6)$, stillbirth $(n=3)$, and fetal death $(\mathrm{n}=5)$. Table 2 summarises the pregnancy outcome according to the date of HELLP onset. Fetal death and stillbirth were observed only in HELLP occurring during the second trimester. Apart from two women (one who developed HELLP at 36 weeks' gestation and another in the postpartum period), all deliveries were made by caesarean section. The main paediatric complications were observed in

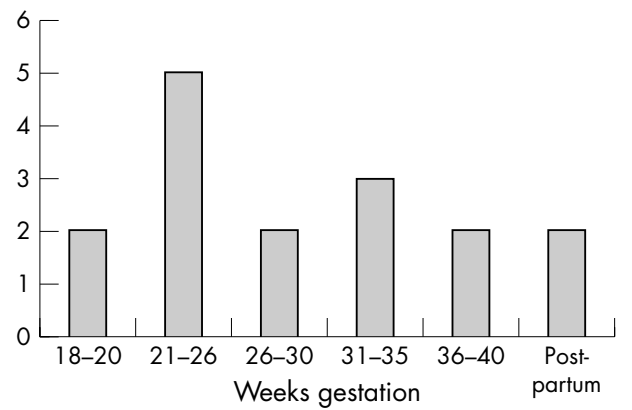

Figure 1 Date of HELLP onset in APS.
Table 1 Main characteristics of HELLP complicating the APS and comparison with series of HELLP in referral obstetric centres

\begin{tabular}{|c|c|c|c|c|}
\hline & $\begin{array}{l}\text { APS present } \\
\text { series }(n=16)\end{array}$ & $\begin{array}{l}\text { Martin } \\
\text { Class3- } \\
\text { Class } 1\end{array}$ & Sibai' & Audibert $^{3}$ \\
\hline \multicolumn{5}{|l|}{ HELLP onset: } \\
\hline Ante-partum & $14(87.5 \%)$ & - & $70 \%$ & - \\
\hline Post-partum & $2(12.5 \%)$ & - & $30 \%$ & - \\
\hline $\begin{array}{l}\text { Elevated } \\
\text { aminotransferase }\end{array}$ & $15(94 \%)$ & $100 \%$ & $100 \%$ & $90 \%$ \\
\hline Thrombocytopenia & $15(94 \%)$ & $100 \%$ & $100 \%$ & $75 \%$ \\
\hline Hypertension & $11(69 \%)$ & $70-90 \%$ & $65 \%$ & - \\
\hline $\begin{array}{l}\text { Proteinuria } \\
>0.5 \mathrm{~g} / \text { day }\end{array}$ & $11(69 \%)$ & $80-90 \%$ & $100 \%$ & - \\
\hline Haemolysis & $10(62.5 \%)$ & $100 \%$ & $100 \%$ & $51 \%$ \\
\hline Abdominal pain & $7(44 \%)$ & $16-50 \%$ & $100 \%$ & $73 \%$ \\
\hline Eclampsia & $5(31 \%)$ & $4-13 \%$ & - & $8 \%$ \\
\hline Ascites & $3(19 \%)$ & - & $32 \%$ & - \\
\hline Seizures & $3(19 \%)$ & - & - & - \\
\hline Coagulopathy & $2(12.5 \%)$ & $8-32 \%$ & $21 \%$ & $11 \%$ \\
\hline
\end{tabular}

a 25 week old premature newborn, who developed a severe membrane hyaline disease evolving towards bronchopulmonary dysplasia. The child needed mechanical ventilation for 43 days, and this period was complicated by multiple infections, metabolic anomalies, enterocolitis, neutropenia, and thrombocytopenia. Craniosynostosis needed surgical repair 1 year later. At the present time, this child continues to have retarded stature.

Pre-eclampsia was present in six cases and eclampsia in five. Among these 11 cases, outcome of pregnancy was: fetal deaths $(n=4)$, stillbirth $(n=3)$, and delivery of hypotrophic $(\mathrm{n}=3)$ or eutrophic $(\mathrm{n}=1)$ liveborns. One woman had an abrupted placenta. No hepatic infarction was observed.

Maternal therapy included anti-hypertensive therapy, transfusion, and other supportive care, including mechanical ventilation for 4-14 days in three women. Dexamethasone or betamethasone were prescribed in order to accelerate fetal maturation. No patient needed plasma exchanges, and none of the women died. One woman remained hypertensive and needed permanent medication.

Six women had seven subsequent pregnancies, 3-6 years after the pregnancy complicated by HELLP (table 3). HELLP recurred at 33 weeks' gestation in one woman (patient 1) with SLE treated with prednisone, hydroxychloroquine, aspirin, and enoxaparin. Caesarean section delivered a $2100 \mathrm{~g}$ live born child, and a rapid remission of laboratory abnormalities followed. One woman became pregnant after in vitro fertilisation and embryo transfer but pregnancy ended in fetal death despite prednisone, hydroxychloroquine, and enoxaparin (patient 2). Four women had five uneventful pregnancies with $100 \mathrm{mg}$ daily aspirin and heparin (patients $3-6)$.

Table 2 Pregnancy outcome in our series according to the date of HELLP onset

\begin{tabular}{|c|c|c|c|}
\hline & $\begin{array}{l}\text { Second } \\
\text { trimester } \\
(\mathbf{n}=7)\end{array}$ & $\begin{array}{l}\text { Third } \\
\text { trimester } \\
(\mathrm{n}=7)\end{array}$ & $\begin{array}{l}\text { Post- } \\
\text { partum } \\
\text { period }(n=2)\end{array}$ \\
\hline Fetal death & 4 & 0 & 0 \\
\hline Stillbirth & 2 & 0 & 0 \\
\hline Livebirth & 1 & 7 & 2 \\
\hline Hypotrophy & 1 & 4 & 2 \\
\hline Caesarean section & 2 & 6 & 1 \\
\hline
\end{tabular}


Table 3 Characteristics of six women with APS complicated with HELLP who had seven subsequent pregnancies

\begin{tabular}{|c|c|c|c|c|}
\hline $\begin{array}{l}\text { Patient } \\
\text { ID/Age }\end{array}$ & Known disease & Prior events & Therapy & Outcome \\
\hline \multicolumn{5}{|l|}{ Case 1} \\
\hline 23 years & SLE/APS & $\begin{array}{l}\text { Normal pregnancy before SLE } \\
\text { onset, } 2 \text { fetal deaths after }\end{array}$ & & \\
\hline 25 years & & HELLP at 31 weeks & $\begin{array}{l}\text { CT } 10 \mathrm{mg} / \text { day, HC, ASP, } \\
\text { LMWH } 8000 \mathrm{U} / \text { day }\end{array}$ & Live birth \\
\hline 28 years & & & $\begin{array}{l}\text { CT } 10 \mathrm{mg} / \text { day, HC, ASP, } \\
\text { LMWH } 8000 \mathrm{~d} / \mathrm{day}\end{array}$ & HELLP at 33 weeks. Live birth \\
\hline \multicolumn{5}{|l|}{ Case 2} \\
\hline $\begin{array}{l}35 \text { years } \\
37 \text { years }\end{array}$ & SLE/APS & $\begin{array}{l}\text { IVFET HELLP at } 18 \text { weeks } \\
\text { IVFET }\end{array}$ & $\begin{array}{l}\text { LMWH } 3000 \mathrm{U} / \text { day } \\
\text { CT } 10 \mathrm{mg} / \text { day, HC, } \\
\text { LWMH } 8000 \mathrm{U} / \text { day }\end{array}$ & $\begin{array}{l}\text { Fetal death } \\
\text { Embryonic loss } 15 \text { days after transfer }\end{array}$ \\
\hline \multicolumn{5}{|l|}{ Case 3} \\
\hline $\begin{array}{l}23 \text { years } \\
25 \text { years }\end{array}$ & SLE/APS & HELLP at 23 weeks & $\begin{array}{l}\text { No } \\
\text { CT } 10 \mathrm{mg} / \text { day, HC, ASP, } \\
\text { LMWH } 4000 \mathrm{U} / \text { day }\end{array}$ & $\begin{array}{l}\text { Fetal death } \\
\text { Live birth at } 37 \text { weeks }\end{array}$ \\
\hline 27 years & & & $\begin{array}{l}\text { CT } 10 \mathrm{mg} / \text { day, HC, ASP, } \\
\text { LMWH } 4000 \mathrm{U} / \text { day }\end{array}$ & Live birth at 38 weeks \\
\hline \multicolumn{5}{|l|}{ Case 4} \\
\hline 28 years & No & $\begin{array}{l}\text { HELLP at } 40 \text { weeks with } \\
\text { eclampsia. Thrombophlebitis in } \\
\text { post-partum period }\end{array}$ & No & Live birth. Diagnosis of primary APS \\
\hline $\begin{array}{l}32 \text { years } \\
\text { Case } 5\end{array}$ & APS & & LWMH 14000 U/day, ASP & Live birth at 38 weeks \\
\hline \multirow[t]{2}{*}{32 years } & $\begin{array}{l}\text { False positive } \\
\text { syphilis serology }\end{array}$ & HELLP at 30 weeks & No & $\begin{array}{l}\text { Live birth but death at } 5 \text { months of } \\
\text { life. Diagnosis of primary APS }\end{array}$ \\
\hline & ÁPS & With eclampsia & LWMH 6000 U/day, ASP & Live birth at 39 weeks \\
\hline $\begin{array}{l}\text { Case } 6 \\
29 \text { years } \\
32 \text { years }\end{array}$ & 1 embryonic loss & $\begin{array}{l}\text { HELPP at } 37 \text { weeks } \\
\text { With eclampsia }\end{array}$ & $\begin{array}{l}\text { No } \\
\text { APS, Calcium heparin } \\
0.6 \mathrm{ml} \times 2\end{array}$ & $\begin{array}{l}\text { Live birth } \\
\text { Live birth at } 39 \text { weeks }\end{array}$ \\
\hline
\end{tabular}

At the present time, all women are doing well, with a mean follow up of 7 years. No vascular complication was observed. All the women with APS characterised only by obstetric complications are being treated with $100 \mathrm{mg}$ daily aspirin, except one woman who has had no therapy. All women with APS with both history of vascular occlusion and obstetric complication are treated with oral anticoagulation. All six women with SLE are in remission with prednisone $(n=4$, with a dose ranging between 2 and $12.5 \mathrm{mg}$ daily) and/or hydroxychloroquine $(\mathrm{n}=6)$.

\section{DISCUSSION}

HELLP syndrome was described in 1982 by Westein as the association of microangiopathic haemolytic anaemia, hepatitis, and thrombocytopenia in a particular group of preeclamptic women, but there are no consensus criteria for its diagnosis. In Martin's study, ${ }^{6}$ HELLP was diagnosed on the basis of thrombocytopenia $\leqslant 150000 / \mu \mathrm{L}$ ), hepatic dysfunction (increased AAT or alanine aminotransferase $\geqslant 40 \mathrm{U} / \mathrm{l}$ ), and haemolysis (increased LDH $\geqslant 600 \mathrm{U} / \mathrm{l}$, progressive anaemia). Martin also classified HELLP on the basis of the platelet count nadir: class 1 when platelet nadir is $\leqslant 50000 / \mathrm{mm}^{3}$, class 2 at $50000-100000 / \mathrm{mm}^{3}$, and class 3 at $100000-$ $150000 / \mathrm{mm}^{3}$. Incidence of eclampsia, epigastric pain, major maternal morbidity, and stillbirth increases as HELLP worsens from class 3 to class 1. In Sibai's study, ${ }^{1}$ HELLP was diagnosed when pre-eclampsia was associated with all the following laboratory abnormalities: characteristic peripheral blood smear, LDH $>600 \mathrm{U} / \mathrm{l}$ (or total bilirubin $>12 \mathrm{mg} / \mathrm{l}$ ), AAT $>70 \mathrm{U} / \mathrm{l}$, and platelet count $<100000 / \mathrm{mm}^{3}$. Audibert ${ }^{3}$ defined complete HELLP by the presence of all three of the following criteria: haemolysis (characteristic peripheral blood smear and $\mathrm{LDH} \geqslant 600 \mathrm{U} / \mathrm{l}$ ), AAT $\geqslant 70 \mathrm{U} / \mathrm{l}$, and platelet count $<100000 / \mu \mathrm{L}$. Partial HELLP was defined by the presence of one or two features of HELLP. Patients with complete HELLP had a higher risk of caesarean section, disseminated intravascular coagulation, and need for transfusion than those with partial HELLP or pre-eclampsia.

The risk of HELLP is probably increased in APS. However, its incidence is difficult to estimate from the literature, especially after the recent changes in APS criteria. ${ }^{2}$ The number of HELLP complicating APS cases reported in the English literature is $<30$. A recent literature review found 10 cases, ${ }^{7}$ to which should be added their two cases, seven cases published in 2002-2003, ${ }^{19-22}$ six earlier cases, ${ }^{8}{ }^{913} 1516$ and a few cases cited in APS pregnancies series. ${ }^{23-25}$ Our series of 75 pregnancies in primary or secondary APS $^{23}$ included seven women (also included in this study), who had eight episodes of HELLP. Backos ${ }^{24}$ reported two HELLP in a series of 150 APS pregnancies. In a placebo controlled study of intravenous immunoglobulin treatment for APS, Branch observed that 6/ 16 women developed severe pre-eclampsia and/or HELLP. ${ }^{25}$ However, most series of APS pregnancies did not report any case of HELLP, ${ }^{26-36}$ although the rate of pre-eclampsia varied between 0 and $51 \%$.

The high rate of HELLP observed in our series (10.6\%), contrasts with $0.66 \%$ in that of Backos; ${ }^{24}$ this can be explained by different recruitment criteria, as Backos included only primary APS without history of thrombophlebitis. On the other hand, the frequency of APS in HELLP is not well known. In our series, HELLP revealed APS in 8/15 cases. HELLP also revealed APS in half of the 24 well described cases in the literature (table 4). A systematic screening of thrombophilia in 93 women with a history of severe pre-eclampsia/HELLP found antiphospholipid antibodies in $66 \%$ of the cases. ${ }^{37}$ Although the cut off level was low $(5 \mathrm{U} / \mathrm{ml})$, the difference in prevalence compared with controls was significant $(p<0.001)$. In France, a systematic search for antiphospholipid antibodies in 68 consecutive cases of complete HELLP among 15000 deliveries, displayed nine 
Table 4 Literature review of 24 well described cases of HELLP syndrome complicating APS

\begin{tabular}{|c|c|c|c|c|}
\hline $\begin{array}{l}\text { Authors, case, age, } \\
\text { age of HELLP onset }\end{array}$ & $\begin{array}{l}\text { History and previous } \\
\text { diagnosis }\end{array}$ & $\begin{array}{l}\text { Antiphospholipid } \\
\text { antibodies/Therapy }\end{array}$ & Fetal outcome & Mother's outcome \\
\hline \multicolumn{5}{|l|}{ Kinoshita $^{8}$} \\
\hline \multicolumn{5}{|l|}{ Case 1} \\
\hline 25 years, 23 weeks & No diagnosis & LA, aCL/No therapy & Fetal death & Liver infarction \\
\hline 29 years, 29 weeks & HELLP, 1 fetal death & No therapy & Live birth & $\begin{array}{l}\text { Pre-eclampsia. Liver infarction. 3rd } \\
\text { pregnancy with live birth with CT }\end{array}$ \\
\hline \multicolumn{5}{|r|}{ 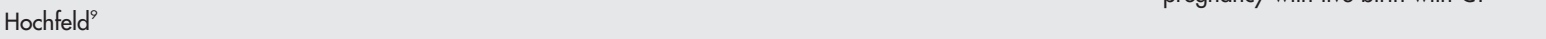 } \\
\hline \multicolumn{5}{|l|}{ Case 2} \\
\hline 37 years, 21 weeks & $\begin{array}{l}\text { Superficial phlebitis, } 3 \\
\text { fetal losses, APS }\end{array}$ & $\mathrm{LA}, \mathrm{aCL} / \mathrm{ASP}$ & Fetal death & Fatal catastrophic syndrome \\
\hline \multicolumn{5}{|l|}{ Ornstein $^{10}$} \\
\hline \multicolumn{5}{|l|}{ Case 3} \\
\hline \multicolumn{5}{|l|}{ Case 4} \\
\hline $\begin{array}{l}33 \text { years, } 18 \text { weeks } \\
\text { llbery }^{11}\end{array}$ & Thrombophlebitis, SLE/APS & LA, aCL/ASP, heparin & Live birth & Skin necrosis \\
\hline \multicolumn{5}{|l|}{ Case 5} \\
\hline 33 years, 37 weeks & No diagnosis & LA, aCL/No therapy & Live birth & $\begin{array}{l}\text { Skin necrosis. Adrenal and liver } \\
\text { infarction }\end{array}$ \\
\hline \multicolumn{5}{|l|}{ Alsulyman ${ }^{12}$} \\
\hline \multicolumn{5}{|l|}{ Case 6} \\
\hline $\begin{array}{l}25 \text { years, } 17 \text { weeks } \\
\text { Case } 7\end{array}$ & Thrombophlebitis, APS & LA/Heparin & Fetal death & \\
\hline $\begin{array}{l}21 \text { years, } 17 \text { weeks } \\
\text { Case } 8\end{array}$ & No diagnosis & LA/No therapy & Fetal death & \\
\hline $\begin{array}{l}24 \text { years, } 19 \text { weeks } \\
\text { Segal }\end{array}$ & No diagnosis & LA, aCL/No therapy & Fetal death & Pre-eclampsia. Liver infarction \\
\hline \multicolumn{5}{|l|}{ Case 9} \\
\hline 27 years, 34 weeks & No diagnosis & $\mathrm{aCl}$ & Live birth & Pre-eclampsia. Budd-Chiari syndrome \\
\hline \multicolumn{5}{|l|}{ Amant $^{14}$} \\
\hline $\begin{array}{l}30 \text { years, } 29 \text { weeks } \\
\text { Case } 11\end{array}$ & Thrombophlebitis & LA/ASP, heparin & Live birth & Liver infarction \\
\hline 29 years, 35 weeks & 1 fetal loss, no diagnosis & $\mathrm{aCL} / \mathrm{ASP}$ & Live birth & Liver infarction \\
\hline \multicolumn{5}{|l|}{ Nagayama ${ }^{15}$} \\
\hline \multicolumn{5}{|l|}{ Case 12} \\
\hline 28 years, 16 weeks & 1 embryonic loss, no diagnosis & $\mathrm{aCL} / \mathrm{No}$ therapy & Induced abortion & \\
\hline \multicolumn{5}{|l|}{ Neuwelt ${ }^{16}$} \\
\hline \multicolumn{5}{|l|}{ Case 13} \\
\hline 31 years, 7 months & $\begin{array}{l}2 \text { fetal deaths, pre-eclampsia, } \\
\text { no diagnosis }\end{array}$ & LA, aCL/No therapy & Neonatal death & $\begin{array}{l}\text { Pre-eclampsia. Catastrophic syndrome } \\
31 \text { years later }\end{array}$ \\
\hline \multicolumn{5}{|l|}{ Mc Mahon ${ }^{17}$} \\
\hline Case 14 & & & & \\
\hline $\begin{array}{l}26 \text { years, } 18 \text { weeks } \\
\text { Fehr }^{18}\end{array}$ & No diagnosis & LA/No therapy & Fetal death & \\
\hline Case 15 & & & & \\
\hline 30 years, 15 weeks & Thrombophlebitis, stroke, SLE & $\mathrm{aCL} / \mathrm{ASP}$ & Fetal death & Liver infarction \\
\hline Sinha ${ }^{19}$ & & & & \\
\hline Case 16 & & & & \\
\hline 26 years, 25 weeks & None, SLE & $\mathrm{aCL} / \mathrm{ASP}$, heparin & Neonatal death & $\begin{array}{l}\text { Pre-eclampsia. Fatal catastrophic } \\
\text { syndrome }\end{array}$ \\
\hline Pauzner ${ }^{20}$ & & & & \\
\hline Case 17 & & & & \\
\hline 33 years, 25 weeks & $\begin{array}{l}13 \text { spontaneous abortions, } \\
\text { popliteal artery and femoral } \\
\text { vein thrombosis, APS }\end{array}$ & LA, aCL/ASP, heparin & Neonatal death & Pre-eclampsia. Liver infarction \\
\hline Case 18 & & & & \\
\hline 37 years, 17 weeks & $\begin{array}{l}1 \text { fetal death, liver infarction, } \\
\text { APS }\end{array}$ & LA, aCL/ASP, heparin & Fetal death & Liver infarction \\
\hline Case 19 & & & & \\
\hline $\begin{array}{l}31 \text { years, } 17 \text { weeks } \\
\text { Case } 20\end{array}$ & 3 fetal deaths, APS & LA, aCL ASP, heparin & Induced abortion & Liver infarction \\
\hline $\begin{array}{l}\text { Case } 20 \\
28 \text { years, } 8 \text { weeks }\end{array}$ & 3 fetal deaths, thrombophlebitis, & LA aCL/Heparin & Induced abortion & Liver infarction \\
\hline & APS & & & \\
\hline Haram $^{21}$ & & & & \\
\hline Case 21 & & & & \\
\hline 28 years, 18 weeks & $\begin{array}{l}\text { Recurrent thrombophlebitis and } \\
\text { fetal losses, APS }\end{array}$ & LA, aCL/ASP, heparin & Induced abortion & \\
\hline Roberts $^{22}$ Case 22 & & & & \\
\hline 30 years, 36 weeks & Fetal death, SLE/APS & LA ASP, heparin & Live birth & $\begin{array}{l}\text { Pre-eclampsia. Renal microangiopathy. } \\
\text { Cerebral haemorrhage }\end{array}$ \\
\hline Queyrel $^{7}$ & & & & \\
\hline Case 23 & & & & \\
\hline 25 years, 27 weeks & 2 fetal deaths, no diagnosis & LA, aCL, No therapy & Live birth & \\
\hline $\begin{array}{l}\text { Case } 24 \\
32 \text { years } 24 \text { weeks }\end{array}$ & & & & \\
\hline 32 years, 24 weeks & Thrombophlebitis, no diagnosis & LA, No therapy & Induced abortion & Skin necrosis \\
\hline
\end{tabular}


positive cases. Seven of these were subsequently tested, and only two were diagnosed as primary APS. Hence, APS prevalence in HELPP is estimated at $3-6 \%{ }^{7}$

In our series, HELLP occurred in $44 \%$ of the cases during the second trimester and $12.5 \%$ at $18-20$ weeks. In a literature review of the 24 well described cases of HELLP complicating APS, HELLP occurred also before 27 weeks' gestation in 16 cases (table 1). Early HELLP onset was described in association with APS as early as at 8 weeks' gestation. ${ }^{20}$ In Sibai's study, ${ }^{1}$ HELLP occurred in $2.5 \%$ of the cases at $17-20$ weeks, in $71 \%$ of the cases at $27-36$ weeks, in $18 \%$ at $37-42$ weeks, and in $30 \%$ during the post-partum period.

HELLP appears more severe in APS than in the general population. In our series, more than two thirds of the cases were associated with pre-eclampsia/eclampsia, and two cases were complicated by microangiopathic coagulopathy. Six of the 24 cases of well described HELLP complicating APS were associated with pre-eclampsia (table 1). We did not observe any case of liver infarction, which Pauzner found to be almost always associated with APS. ${ }^{20}$ In one case of HELLP in APS, hepatic involvement was due to complete thrombosis of hepatic veins. ${ }^{13}$

HELLP may also be part of the catastrophic syndrome, similarly to Hochfeld's case. ${ }^{9}$ Catastrophic APS is an acute and devastating disseminated coagulopathy defined by the clinical involvement of at least three different organ systems over a short period. ${ }^{38}$ One fatal case of HELLP with catastrophic syndrome was characterised by bone marrow necrosis. ${ }^{19}$

In our study, all HELLP resolved with delivery and/or supportive care. There was no case of maternal death, similarly to the series of Backos and Branch. ${ }^{24}{ }^{25}$ In the general population, HELLP syndrome mortality is about $1 \%{ }^{1}$ In the literature, besides the catastrophic syndrome, some cases of HELLP complicating APS were refractory to corticosteroids and anticoagulation. Treatment of refractory HELLP is not standardised. Remission may be observed after plasma exchanges. ${ }^{22}$ Dexamethasone appeared to be more effective than betamethasone. ${ }^{39}$ Combination of plasma exchanges with fresh frozen plasma has been advocated. ${ }^{1}$ In our studies, six women had seven subsequent pregnancies treated with aspirin plus LMWH; one pregnancy was complicated by HELLP recurrence but resulted in live birth, another one with embryonic loss. The other pregnancies ended in live birth. There are no data concerning the risk of HELLP recurrence in APS. Of four cases of HELLP complicating APS, Pauzner reported one recurrence of liver infarction despite aspirin and $60 \mathrm{mg}$ daily enoxaparin. ${ }^{20}$ In the general population, HELLP recurred in $5 \%$ of subsequent pregnancies in women with a history of HELLP at $\leqslant 30$ weeks' gestation. ${ }^{40}$

In conclusion, APS may be revealed by the HELLP syndrome. Search for antiphospholipid antibodies is mandatory in such circumstances. In APS, HELLP is associated with pre-eclampsia/eclampsia in most cases, and seems to occur earlier than in the general population. Heparin plus aspirin may prevent obstetric complications in the subsequent pregnancies.

\section{Authors' affiliations}

D Le Thi Thuong, N Tieulié, N Costedoat, M-R Andreu, B Wechsler, J-C

Piette, Departments of Internal Medicine, Groupe Hospitalier PitiéSalpêtrière, 47-83 Boulevard de l'Hôpital, 75651 Paris cedex 13, France

D Vauthier-Brouzes, Departments of Obstetrics, Groupe Hospitalier Pitié-Salpêtrière, 47-83 boulevard de l'Hôpital, 75651 Paris cedex 13, France

O Aumaître, Department of Internal Medicine, Hôpital Gabriel Montpied, BP 69, 63003 Clermond-Ferrand cedex 1, France

\section{REFERENCES}

1 Sibai BM, Ramadan MK, Usta I, Salama M, Mercer BM, Friedman SA. Maternal morbidity and mortality in 442 pregnancies with hemolysis, elevated liver enzymes, and low platelets (HELLP) syndrome. Am J Obstet Gynecol 1993; 169:1000-6.

2 Wilson WA, Gharavi AE, Koike T, Lockshin MD, Branch DW, Piette JC, et al. International consensus statement on preliminary classification criteria for definite antiphospholipid syndrome. Arthritis Rheum 1999;42:1309-11.

3 Audibert F, Friedman SA, Frangieh AY, Sibai BM. Obstetrics: clinical utility of strict diagnostic criteria for the HELLP (hemolysis, elevated liver enzymes and low platelets) syndrome. Am J Obstet Gynecol 1996;175:460-4.

4 Hochberg MC. Updating the American College of Rheumatology revised criteria for the classification of systemic lupus erytematosus. Arthritis Rheum 1997:40:1725-34.

5 Branch W. Antiphospholipid antibodies and reproductive outcome: the current state of affairs. J Reprod Immunol 1998;38:75-87.

6 Martin JN, Rinehart BK, May WL, Magann EF, Terrone DA, Blake PG. The spectrum of severe preeclampsia: comparative analysis by HELLP (hemolysis, elevated liver enzyme levels, and low platelet count) syndrome classification. Am J Obstet Gynecol 1999;180:1373-84.

7 Queyrel V, Ducloy-Bouthors AS, Michon-Pasturel U, Hachulla E, Dubucquoi S, Caron C, et al. Anticorps antiphospholipides au cours du syndrome HELLP. étude clinique et biologique à partir de 68 patientes. Revue Méd Interne 2003;24:158-64.

8 Kinoshita K. Hepatic infarction during pregnancy complicated by antiphospholipid syndrome. Am J Obstet Gynecol 1993;169:199-202.

9 Hochfeld M, Druzin ML, Maia D, Wright J, Lambert RE, McGuire J. Pregnancy complicated by primary antiphospholipid syndrome. Obstet Gynecol 1994;83:804-5.

10 Ornstein MH, Rand JH. An association between refractory HELLP syndrome and the antiphospholipid antibodies during pregnancy. A report of 2 cases. $J$ Rheumatol 1994;21:1360-4.

11 Ilbery M, Jones AR, Sampson MB, Samson J. Lupus anticoagulant and HELLP syndrome complicated by placental abruption, hepatic, dermal and adrenal infarction. Aust NZ J Obstet Gynecol 1995;35:215-7.

12 Alsulyman OM, Castro MA, Zuckerman E, McGehee W, Goodwin TM. Preeclampsia and liver infarction in early pregnancy associated with the antiphospholipid syndrome. Obstet Gynecol 1996;88:644-6.

13 Segal S, Senhav S, Segal O, Zohav E, Gemer O. Budd-Chiari syndrome complicating severe preeclampsia in a parturient with primary antiphospholipid syndrome. Eur J Obstet Gynecol Reprod Biol 1996:68:227-9.

14 Amant F, Spitz B, Arnout J, Van Assche FA. Hepatic necrosis and haemorrhage in pregnant patients with antiphospholipid antibodies. Lupus 1997;6:552-5.

15 Nagayama K, Izumi N, Miyasaka Y, Saito K, Ono K, Noguchi O, et al. Hemolysis, elevated liver enzymes, and low platelets syndrome associated with primary anti-phospholipid antibody syndrome. Intern Med 1997;36:661-6.

16 Neuwelt CM, Daikh DI, Linfoot JA, Pfister DA, Yong RG, Webb RL, et al. Catastrophic antiphospholipid syndrome. Response to repeated plasmapheresis over three years. Arthritis Rheum 1997;40:1534-9.

17 McMahon LP, Smith J. The HELLP syndrome at 16 weeks gestation: possible association with the antiphospholipid syndrome. Aust N Z J Obstet Gynaecol 1997:37:313-14.

18 Fehr T, Cathomas G, Weber C, Fontana A, Schaffner A. Foetal loss, liver necrosis and acute lupus erythematosus in a patient with antiphospholipid antibody syndrome. Lupus $2001 ; 10: 576-9$.

19 Sinha J, Chowdhry I, Sedan S, Barland P. Bone marrow necrosis and refractory HELLP syndrome in a patient with catastrophic antiphospholipid antibody syndrome. J Rheumatol 2002;29:195-7.

20 Pauzner R, Dulitzky M, Carp H, Mayan H, Kenett R, Farfel Z, et al. Hepatic infarctions during pregnancy are associated with the antiphospholipid syndrome and in addition with complete or incomplete HELLP syndrome. J Thromb Haemost 2003:1758-63.

21 Haram K, Trovik J, Sandset PM, Hordnes K. Severe syndrome of hemolysis, elevated liver enzymes and low platelets (HELLP) in the 18th week of pregnancy associated with the antiphospholipid-antibody syndrome. Acta Obstet Gynecol Scand 2003;82:679-80.

22 Roberts G, Gordon MM, Porter D, Jardine AG, Gibson IW. Acute renal failure complicating HELLP syndrome, SLE and anti-phospholipid syndrome: successful outcome using plasma exchange therapy. Lupus 2003;12:251-7.

23 Le Thi Huong D, Wechsler B, Bletry O, Vauthier-Brouzes D, Lefebvre G, Piette JC. A study of 75 pregnancies in patients with the antiphospholipid syndrome. J Rheumatol 2001;28:2025-30.

24 Backos M, Rai R, Baxter N, Chilcott IT, Cohen H, Regan L. Pregnancy complications in women with recurrent miscarriage associated with antiphospholipid antibodies treated with low dose aspirin and heparin. Br J Obstet Gynaecol 1999; 106:102-7.

25 Branch DW, Peaceman AM, Druzin M, Silver RK, El-Sayed Y, Silver RM, Spinnato J, Harger J. A multicenter, placebo-controlled pilot study of intravenous immune globulin treatment of antiphospholipid syndrome during pregnancy. Am J Obstet Gynecol 2000;182:122-7.

26 Kutteh WH. Antiphospholipid antibody-associated recurrent pregnancy loss: treatment with heparin and low-dose aspirin is superior to low-dose aspirin alone. Am J Obstet Gynecol 1996; 174:1584-9.

27 Lima F, Khamashta MA, Buchanan NMM, Kerslake S, Hunt BJ, Hughes GRV A study of sixty pregnancies in patients with the antiphospholipid syndrome. Clin Exp Rheumatol 1996; 14:131-6. 
28 Rai R, Clifford K, Cohen H, Regan L. High prospective foetal loss rate in untreated pregnancies of women with recurrent miscarriage and antiphospholipid antibodies. Hum Reprod 1995;10:3301-4

29 Rosove MH, Tabsh K, Wasserstrum N, Howard P, Hahn BH, Kalunian KC. Heparin therapy for pregnant women with lupus anticoagulant or anticardiolipin antibodies. Obstet Gynecol 1990;75:630-4

30 Ruffatti A, Orsini A, Di Leonardo L, Nardelli GB, Patrassi GM, Truscia D, et al. A prospective study of fifty-three consecutive calcium heparin treated pregnancies in patients with antiphospholipid antibodies-related foetal loss. Clin Exp Rheumatol 1997; 15:499-505.

31 Silveira LH, Hubble CL, Jara U, Saway S, Martinez-Osuna P, Seleznick MJ et al. Prevention of anticardiolipin antibody-related pregnancy losses with prednisone and aspirin. Am J Med 1992;93:403-11.

32 Silver RK, McGregor DO, Sholl JS, Hobart JM, Neerhof DO, Ragin A Comparative trial of prednisone plus aspirin versus aspirin alone in the treatment of anticardiolipin antibody-positive obstetric patient. Am J Obste Gynecol 1993;169:1411-17.

33 Balash J, Carmona F, Lopez-Soto A, Font J, Creus M, Cabregues F, et al. Low-dose aspirin for prevention of pregnancy losses in women with primary antiphospholipid syndrome. Hum Reprod 1993; 12:2234-39.

34 Cowchock FS, Reece EA, Balaban D, Branch DW, Plouffe L. Repeated foetal losses associated with antiphospholipid antibodies: a collaborative randomized trial comparing prednisone with low-dose heparin treatment. Am J Obstet Gynecol 1992;166:1318-23.

35 Hasegawa I, Takakuwa K, Goto S, Yamada K, Sekizuka N, Kanazawa K, ef al. Effectiveness of prednisolone/aspirin therapy for recurrent aborters with antiphospholipid antibody. Human Reprod 1992;7:203-7.

36 Branch DW, Silver RM, Blackwell JL, Reading JC, Scott JR. Outcome of treated pregnancies in women with antiphosholipid syndrome: an update of the Utah experience. Obstet Gynecol 1992;80:614-20.

37 von Tempelhoff GF, Heilmann L, Spanuth E, Kunzmann E, Hommel G. Incidence of the factor $V$ Leiden-mutation, coagulation inhibitor deficiency and elevated antiphospholipid antibodies in patients with preeclampsia or HELLP syndrome. Thromb Res 2000;100:363-5.

38 Asherson RA, Cervera R, Piette JC, Shoenfeld Y, Espinosa G, Petri MA, et al. Catastrophic antiphospholipid syndrome: clues to the pathogenesis from a series of 80 patients. Medicine (Baltimore) 2001;80:355-377.

39 Isler CM, Barrilleaux PS, Magann EF, Bass JD, Martin JN. A prospective, randomized trial comparing the efficacy of dexamethasone and betamethasone for the treatment of antepartum HELLP (hemolysis, elevated liver enzymes, and low platelet count) syndrome. Am J Obstet Gynecol $2001 ; 184: 1332-9$

40 McKinney ET, Haddad B, Barton JR, Livingston JC, Sibai BM. Subsequent pregnancy outcomes in women with a history of HELLP syndrome $\leqslant 30$ weeks. Am J Obstet Gynecol 2001;184:S79.

\section{$\mathrm{ECHO}$}

\section{Vertebral slippage causes taxi drivers' back pain}

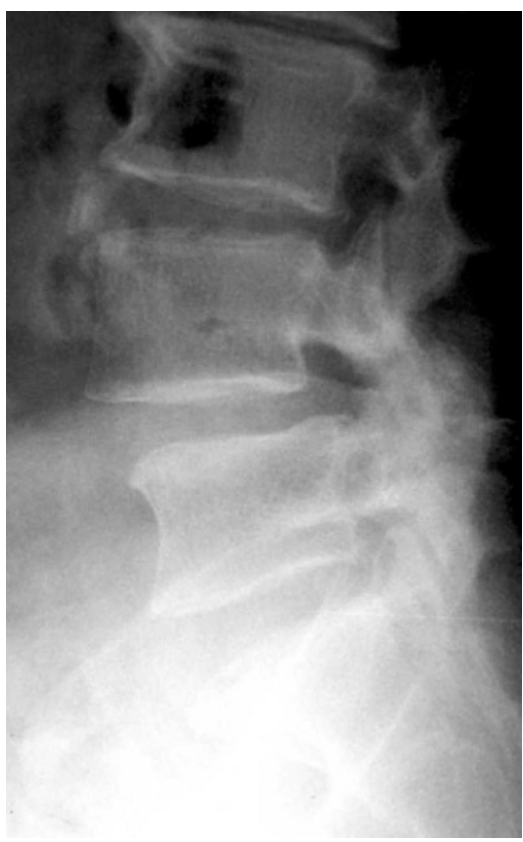

ASL in a male taxi driver: lateral view of grade 1 spondylolisthesis of L4 on L5.
A cross sectional study linking acquired lumbar spondylolisthesis with taxi drivers may ultimately lead to preventive measures against this important cause of disabling back pain. It is the first analytical study to show a link with this occupation.

Not only was taxi driving significantly associated with acquired spondylolisthesis (ASL), those who had worked as taxi drivers longest had the highest risk. Drivers with 15 years' service or more had over three times the risk than drivers with up to 5 years' service, and drivers with 6-15 years' service had almost twice the risk, after adjustment for confounding factors. Age, overweight or obesity, and frequent strenuous exercise were also associated with the condition.

Baseline data from the taxi drivers health study, part of a Taipei city government backed programme to monitor taxi drivers' health, were used for the regression analyses. The data covered a sample cohort of 1242 registered taxi drivers in the city who had been operating for at least one year during the first five months of 2000. ASL was diagnosed as non-lytic spondylolisthesis above L5 from lumbosacral $x$ ray films; demographic data and data about the job and health behaviours were taken from standard self administered questionnaires.

Our knowledge about ASL comes mostly from descriptive work, but identifying the environmental and work factors on which to base preventive measures needs more population based studies. The next step will be to test these results in prospective studies and then to pinpoint work exposures carrying a risk for the condition.

A Chen J-C, et al. Occupational and Environmental Medicine 2004;61:992-998.

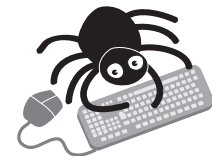

Please visit the Annals of the Rheumatic Diseases website [www.annrheumdis.com] for a link to the full text of this article. 